$14^{\text {th }}$ Conf. Agric. Develop. Res., Fac. of Agric., Ain Shams Univ., March, 2019, Cairo, Egypt

Special Issue, 27(1), 887 - 897, 2019

Website: http://strategy-plan.asu.edu.eg/AUJASCI/

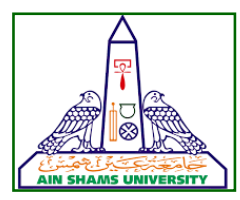

887

\title{
IN-OVO INCULATION OF SELENIUM NANOPARTICLES IMPROVES PRODUCTIVE PERFORMANCE, BLOOD BIOCHEMICAL PROFILE, ANTIOXIDANT STATUS AND IMMUNE RESPONSE OF HATCHED CHICKS
}

\author{
Mohammad $^{1 *}$ N.G., El-wardany ${ }^{2}$ I.E., El-homosany ${ }^{2}$ Y.M., \\ Magda M. Wakwak ${ }^{1}$, Sabic ${ }^{1}$ E.M. and Ibrahim ${ }^{1}$ N.S.
}

1- Biological Application Dept., Nuclear Res. Cent., Atomic Energy Authority, Egypt

2- Poultry Production Dept., Fac. of Agric., Ain Shams Univ., P.O. Box 68, Hadayek Shubra 11241, Cairo, Egypt

*Corresponding author: noureldeen.goda@gmail.com

Received 30 December, 2018

Accepted 13 January, 2019

\section{ABSTRACT}

Selenium is a trace element essential in animal nutrition and exerts multiple actions related to enhance animal production, fertility, immune response and antioxidant defense system of chickens. The aim of the present study is investigating the benefit effects of selenium nanoparticles (SEN) in-ovo injection on productive performance, express stimulate antioxidant defense system and immune response of hatched chicks. A total of 210 broiler breeder eggs ( Habbard Star-Bro) were divided into three in-ovo injection treatment groups,( 0, 5 and 10 ppm SEN) and incubated. Hatchability traits, productive performance, biochemical profile, antioxidant status and immune response of hatched chicks were estimated. Results indicated significant increase in HDLcholesterol, T3, GSR, GSH, IGA, IGM and IGG as affected by in-ovo inoculated SEN levels. However feed conversion ratio, triglycerides and MDA significantly decreased by in-ovo treatments. No significant alternations were recorded in hatched chicks weight, feed intake, body weight, body weight gain, carcass characteristics, and serum levels of protein fractions, cholesterol, LDL- cholesterol, ALT, AST, ALP, uric acid, creatinine and glucose in in-ovo treated groups compared with the control one. It is summarized that, in-ovo inoculation of different levels of SEN can improve feed conversion ratio, lipid profile, antioxidants status and immunity of broiler hatched chicks.

Keywords: Selenium; Chicks; Fertility

\section{INTRODUCTION}

Selenium is a trace element essential in animal nutrition and exerts multiple actions related to animal production, fertility, and disease prevention. In addition Selenium (Se) is well known to be essential for growth (Yoon et al 2007, Wang and $X u$, 2008), feather development (Edens et al., 2001, Perić et al 2009) of chickens. Previous studies have also shown that Se injected into the egg is potentially toxic to chick embryos. (Macalintal, 2012), reported that, The effect of injecting graded levels of Se at 20, 40 and $60 \mu \mathrm{g} / \mathrm{egg}$ either as SeMet or $\mathrm{Na} 2 \mathrm{SeO} 3$ did not produce any physical deformities in embryos by d 18 and 20 of incubation, as shown the $60 \mu \mathrm{g}$ Se dose, \% livability was higher $(P<0.05)$ for embryos injected with Se-Met compared with $\mathrm{Na} 2 \mathrm{SeO} 3$. In another study to the same author with broiler eggs using injection doses up to $40 \mu \mathrm{g}$ Selegg, Se-Met injection resulted in higher hatchability. Numerous reports have demonstrated that selenium was the co-factor and activator of $5^{\prime}$ deiodinase that was a key enzyme of triiodothryonine (T3) synthesis, and T3 was the growth control component of animals particularly poultry by controlling the body's energy and protein assimilation, and thus could regulate animal growth (Özbal et al 2008). Selenium is an essential trace element that up regulates a major component of the antioxidant defense mechanism by controlling the body's glutathione pool and its major Se-containing antioxidant enzyme. Approxi- 
mately $30-40 \%$ of selenium exist in the form of GSH-Px in animal body tissue, and lots of animal diseases and dysfunction were caused by GSH-Px activity change that aroused by selenium deficiency (Pilarczyk et al 2012). Dietary selenium is essential for the activity of virtually all arms of the immune system (Surai and Dvorska, 2002). (Levkut et al 2009) suggested that the effect of organic Se in increasing the concentration of circulating $T$ and $B$ cells is important in restoring the leukocyte subpopulation in chicks fed a deoxynivalenol (DON) contaminated diet, leading to increases in cellular phagocytic activity.

\section{MATERIAL AND METHODS}

The aim of this study was to investigate the effect of selenium nanoparticles (SEN) in-ovo injection on productive performance, express stimulate antioxidant defense system and immune response of hatched chicks. A total of 210 broiler breeder eggs (Habbard Star-Bro) were obtained from a local hatchery (El-Tokhy Co., New Salhia, Egypt) from a maternal flock 54 week of age. Eggs were incubated at $37.8^{\circ} \mathrm{C}$ and $60 \% \mathrm{RH}$. Eggs were individually weighed and divided into three treatment groups, with approximately similar average egg weight per group $(56.5 \pm 0.2 \mathrm{~g})$. The first treatment non ovo-injected, and considered the control group, where the second and the third treatments were ovo injected with $100 \mu \mathrm{L}$ of nano-Selenium enriched yeast with concentrations of $5,10 \mathrm{ppm}$ resperticavely. Nano - Selenium was obtained from Department of physics, Faculty of Science, Mansora University, Mansora, Egypt.

Eggs were candled at day 7 and 14 of incubation and either unfertilized or died embryos were removed. Those eggs containing live embryos were randomly re-allotted eggs to the experimental groups equally (65eggs in each). At 14 day of incubation, all eggs in the second and third groups were injected with $100 \mu \mathrm{L}$ of their respective solution into the air cell according to the procedure described by (Bhanja et al 2004). Prior injection, both of the working bench and the eggs were disinfected with $70 \%$ ethanol and the shell was punched at the width end of the egg to make a hole with a 21-ga needle. Then, the eggs were injected with a 23-ga needle. At day 21 of incubation, hatched chicks, within each treatment group, were individually weighed then its respective values and values of hatchability were recorded.

\section{Experimental birds and diet}

The hatched chicks, from each treatment were immediately assigned to three pens per treatment $(100 \times 60 \times 50 \mathrm{~cm}$; length $\times$ width $\times$ height $)$, with ad libitum access to water and feed, at the same managerial, controlled, clean and hygienic environmental conditions. Vaccination against the Newcastle disease (ND) virus was performed on days 21 and 28 of age using an eye dropper (Live Lasota strain; KBNP, Inc.; Hungnam, Korea). Artificial light source was used in order to provide 24 hours of light per day throughout the first week, then reduced to $22 \mathrm{~h}$ for the other experimental periods.

The experimental basal diet was purchased from Salah Attia Co.,

Tafahna El-Ashraf, Egypt, which formulated to meet the recommendations of (NRC, 1994). The composition and calculated chemical analysis of the basal diet are presented in Table (1).

\section{Measurements}

\section{Hatchability and embryonic mortality}

Hatchability percentage was recorded and calculated as follows:

\section{Hatchability (\%)=}

\section{$\frac{\text { Number of hatched chicks }}{\text { Number of fertile eggs prior to injection }} \times 100$}

\section{Growth performance parameters}

Live body weight (LBW) per replicate was individually recorded once weekly in early morning. Average daily body weight gain (BWG) was weekly calculated as the difference between current and previous weight divided by seven days. Daily feed intake $(\mathrm{FI})$ and feed conversion ratio (FCR) per bird were calculated weekly. Overall BW gain, FC, and FCR were calculated for the whole duration of the experiment. At 35 day of age, six representative birds were randomly taken from each treatment group, fasted for 12 hours before slaughtering, individually weighted. Birds were manually slaughtered by cutting the jugular veins of the neck by sharp knife, and the slaughtered birds were defeathered, opened and the hot carcass was weighted. Edible offals were weighted as proportional value to live pre-slaughtering weight. Carcass yield was calculated as follows: 
In-Ovo Inculation of Selenium Nanoparticles Improves Productive Performance, Blood Biochemical Profile, Antioxidant Status and Immune Response of Hatched Chicks

\author{
Empty carcass weight $(g)+$ \\ edible offals weight $(g)$ \\ Carcass yield = ---------------------------- $\times 100$ \\ Live pre-slaughtering weight
}

\section{Biochemical parameters}

At the end of the experimental period, six chicks from each group were randomly chosen and scarified in a horizontal position to reduce the antiperistalsis movement of intestinal segments and regurgitation of their contents. Birds were sacrificed, bled individually into siliconized tubes. Upon coagulation blood were centrifuged at $4000 \mathrm{rpm}$ for $15 \mathrm{~min}$. The serum was separated from the other tube stored in deep freezer at $\left(-20^{\circ} \mathrm{C}\right)$ until the biochemical analysis. The following biochemical parameters were determined: aspartate aminotransferase (AST), alanine aminotransferase $(A L T)$ and alkaline phosphatase (ALP), uric acid (UA), creatinine (CR), glucose and antioxidant parameters were determined spectrophotometerically using commercial kits as described by the manufacturer company (SpinreactCo., Spain) according to (Ishihard et al 1972). Serum total proteins values $(\mathrm{g} / \mathrm{dl})$ were obtained according to the method described by (Henry, 1974). Serum cholesterol, HDL and LDL-cholesterol (mg/dl) were determined according to the method of (Richmond, 1973). Triiodothyronine (T3) were determined by using Gamma-Coat 125I RIA Kits, according to (Britton et al 1975). Serum $\lg A$, IgM, and $\lg G$ concentrations was recorded as total serum Ig concentration (Mountzouris et al 2010).

\section{Statistical analysis}

Data of the experiment for all variables were subjected to ANOVA as a completely randomized design according to (Snedcor and Cochran, 1982), Procedure of the Statistical Analysis System (SPSS, version, 18.0; 2010). The following model was used: $\mathbf{Y i j}=\boldsymbol{\mu}+\mathbf{T i}+\mathbf{e i j}$, where: $\mathbf{Y i j}=$ An observation, $\boldsymbol{\mu}=$ general mean, $\mathbf{T i}=$ fixed effect of ied treatment levels ( $i=0,5$ and $10 \mathrm{PPm}$ ), eij= Experimental error of the model. Differences among treatments were tested statistically with New Multiple Range test method according to (Duncan, 1955).

\section{RESULTS AND DISCUSSION}

Hatchability, embryonic mortality and chicks body weight at hatch

Hatchability (\%) and body weight at hatch (BWH) are presented in Table (2), it is clearing from the data illustrated in the table that, hatchability and embryonic mortality rates were significantly affected by inovo injection nano-Selenium (Se) for broiler eggs. The control group recorded the highest hatchability value, while the $10 \mathrm{ppm}$ inovo nano-Se group recorded the lowest hatchability percentage, followed by the $5 \mathrm{ppm}$ nano-Se group, however, chick body weight had no significant differences between the treatments group and the control one. Although selenium had been credence as an essential trace mineral in poultry nutrition, dietary Se deficiency in poultry can lead to symptoms such as reduced fertility and reduced hatchability as well as reduced egg production (Latshaw et al 2004). Therefore, Se must be used in a limited levels because Se injection into the egg with relatively high doses may be exert a potential toxic effect to avian embryos. Our injection doses were in the limit levels not over doses, it had not find any abnormalities, such as inflammation of the neck and head region, as well as beak, leg and toe deformities, but the reasons for these different results can be attributed to many factors such as delivery technique, mineral form, day of incubation, route of injection (air cell, amnion or yolk) and inoculated dose. In agreement with our results, (Macalintal, 2012) indicated that, the effects of graded doses $(0,2.5,5,10$ and $20 \mu \mathrm{g} / \mathrm{egg})$ of Se either Se-Met or $\mathrm{Na} 2 \mathrm{SeO} 3$ injection on embryo viability $10 \mathrm{~d}$ post-Se injection was embryo viability ranged from 84 to $97 \%$ for eggs injected with graded doses of Se-Met and from 74 to $94 \%$ for those injected with $\mathrm{Na2SeO3.} \mathrm{The} \mathrm{same} \mathrm{author} \mathrm{in} \mathrm{another} \mathrm{study} \mathrm{find}$ that injection graded levels of Se up to $60 \mu \mathrm{g} / \mathrm{egg}$ either as $\mathrm{Se}-\mathrm{Met}$ or $\mathrm{Na2SeO} 3$ did not produce any physical deformities in embryos by d 18 and 20 of Incubation.

\section{Live body weight and body weight gain}

Table (3), LBW was improved significantly $(P<0.05)$ in the injected groups $(R 2$ and $R 3)$ in the first week, and in the experimental periods but not significant. The highest values of LBW were 
observed in R3. BWG was improved significantly $(P<0.01)$ in the injected groups (R2 and $R 3)$ in the all experimental periods, except the periods (8-14 and 22-28 day) and the total gain of live body weight but not significant. The highest values of BWG were observed in R2 and R3. The improvement in LBW and BWG may be due to the vital role of selenium, which can be summarized in that, selenium was act as a co-factor and activator of $5^{\prime}$ deiodinase that was a key enzyme of triiodothryonine (T3) synthesis, and T3 was the growth control component of animals particularly poultry by controlling the body's energy and protein assimilation, and thus could regulate animal growth (Özbal et al 2008). In a study by (Jianhua et al 2000) , Se-deficient chickens showed significant reductions in T3 and elevated T4 levels compared with Se-supplemented chickens. Likewise, 5 'deiodinase activity was lower. Also, it may be due to the fact that, selenium deficiency lead to muscles destroy and supplementation of selenium not only prevent of this case, but also increase the rate of skeletal muscle breakdown. This is in agreement with (Brown et al 1981) who concluded that Se supplementation in rats increased muscle protein breakdown leading to heavier body weights. A similar trend was also reported by (Zhou and Wang, 2011) consisted of the basal diet supplemented with, $0.0,0.1,0.3$, and 0.5 $\mathrm{mg} / \mathrm{kg}$ of Nano-Se respectively, improved final BW, daily $B W$ gain (DWG), feed conversion ratios, and survival rate $(P<0.05)$ were observed in the groups supplemented with nano-Se as compared with the control groups after $90 \mathrm{~d}$ of feeding.

\section{Feed consumption and feed conversion ratio}

feed consumption (FC) of broiler chicks was significantly $(P<0.05$ and $P<0.01)$ changed as a results of in ovo injection with different doses of nano-Se, the FC values tended to increment in the injected groups specially in the all periods after hatch except the period 22-29 day and total fee consumption (TFC). While feed conversion ratio was significantly $(P<0.05$ and $P<0.01)$ improved in the injected groups for the periods (15-21 and 2935 day), and the total period but not significant. The improvement in feed efficiency resulting from utilization Nano-Se may be partially due to nanoSe exhibit novel characteristics such as a large surface area, high surface activity, high catalytic efficiency, strong adsorbing ability, and low toxicity (Zhang et al 2001, Wang and $X u, 2008$ ). Also, organic $\mathrm{Se}$ is involved in regulation of enzymatic systems interfering in energetic metabolism and metabolism of the essential fatty acids, purinic and pyrimidinic bases (Ebeid et al 2013). On the other hand, triiodothyronine is a main hormone controlling the body's energy and protein anabolism. In agreement with the present results, (El-Deep et al 2016), indicated that, feeding compound of Aspergillus awamori and Se nano-particles improved significantly feed convertion ratio and decreased feed intake in chickens.

\section{Carcass characteristics}

Carcass characteristics of Habbard-Starpro broiler chicks are presented in Table (5), and it was showed that,all the examined carcass traits (carcass weight $(\%)$, breast weight (\%), thigh weight $(\%)$, total edible weight $(\%)$, heart weight $(\%)$, gizzard weight (\%), liver weight (\%), spleen weight (\%), thymus weight (\%),bursa weight (\%) and carcass yield (\%) were not affected significantly $(\mathrm{P}>0.05)$ by in ovo injection with different doses of nano-Se. In line with the present results, (Khazraie et al 2015) indicated that no significant effect on carcass composition ( $p>0.05$ ) of chicks fed diets with Selenium Nano particles,sodium silent and control, and increase in use of nanoSelenium was more tender than sodium Selenite group, but not significant. On the other hand (EIDeep et al 2016) revealed that, high ambient temperature significantly depressed breast muscle weight, and abdominal fat weight, while feeding nano- Se clearly alleviated these negative effects of high ambient temperature. In the same trend, (Cai et al 2012) reported that, there were no significant differences $(P>0.05)$ in immune organ index (thymus, bursa, and spleen) of broiler chicks due to supplementation with nano-Se.

\section{Biochemical parameters}

Results of blood biochemical parameters are presented in Tables (6, 7, 8, 9, 10, 11 and12). Liver enzymes, renal function, protein fractions, cholesterols, LDL and glucose level were not significant affected by the in-ovo injection broiler eggs with fragment doses of nano-Se. While, it was found enhancement effects for inoculation nano-Se particles to the broiler eggs, where the antioxidants parameters ( GSR, GSH and MDA ), immune response parameters ( IGG, IGM and IGA ), triglycerides, HDL and T3 were improved significantly as affected by in-ovo injection fragment doses of 
nano-Se. Excessive reactive oxygen species (ROS) formation levels disturb the balance between oxidation and antioxidant defense systems, resulting in lipid peroxidation (Shimizu et al 2006) and oxidative damage to proteins, DNA and vital biological molecules, cause of this the antioxidant system include numerous antioxidant enzymes, such as glutathione peroxidase (GSH-Px), superoxide dismutase (SOD), and catalase (CAT) (Surai, 2002a). Natural antioxidants play vital roles in protecting cells from ROS by reducing free radicals and preventing the peroxidation of lipids (Grashorn, 2007). Selenium is an essential trace element that up regulates a major component of the antioxidant defense mechanism by controlling the body's glutathione pool and its major Secontaining antioxidant enzyme. Approximately 30$40 \%$ of selenium exist in the form of GSH-Px in animal body tissue, and lots of animal diseases and dysfunction were caused by GSH-Px activity change that aroused by selenium deficiency (Pilarczyk et al 2012). Dietary selenium is essential for the activity of virtually all arms of the immune system (Surai and Dvorska, 2002b). Feeding nano-Se increased mRNA expression of cytokine genes (interleukins 2 and 6) under both thermoneutral and high ambient temperature conditions. The balance between reactive oxygen species (ROS) production and the antioxidant system must be established to maintain immune function, health, and productivity (Surai, 2002a). (Cai et al 2012), reported that, There were no significant differences $(P>0.05)$ in immune organ index (thymus, bursa, and spleen) of broiler chicks due to supplementation with nano-Se, but a significant quadratic effect of nano-Se was observed on contents of IgM in serum. (Levkut et al 2009) suggested that the effect of organic Se in increasing the concentration of circulating $T$ and $B$ cells is important in restoring the leukocyte subpopulation in chicks fed a deoxynivalenol (DON) contaminated diet, leading to increases in cellular phagocytic activity. Also, (Khazraie et al 2015) observed that serum total protein, globulin, AST and urea were increased linearly and quadratically in nano-Se supplemented group at 8 week of age compare to sodium selenite group, whereas, serum cholesterol, triglycerides, AlG ratio and ALP decreased.

In conclusion, in-ovo inoculation of different levels of selenium nano particles can improve feed conversion ratio, lipid profile, antioxidants status and immunity of broiler hatched chicks.
Table 1. Ingredients and calculated chemical composition of the basal diet

\begin{tabular}{|l|c|c|}
\hline Ingredients & Starter & Grower \\
\hline Yellow corn & 58.50 & 62.50 \\
Soybean meal (44\%) & 26.00 & 23.94 \\
Maize gluten meal (62\%) & 10.00 & 7.00 \\
Vegetable oil & 1.500 & 2.50 \\
Limestone & 1.12 & 1.23 \\
Di-Calcium Phosphate & 1.75 & 1.70 \\
Premix* & 0.30 & 0.30 \\
NaCl (salt) & 0.30 & 0.30 \\
L-lysine & 0.36 & 0.36 \\
DL-Methionine & 0.17 & 0.17 \\
\hline Total & 100 & 100 \\
\hline Calculated composition ${ }^{\star *}$ & & \\
ME (kcal kg-1) & 3058.00 & 3120 \\
Crude protein & 22.45 & 20.20 \\
Calcium & 0.93 & 0.95 \\
Non phytate phosphorus & 0.46 & 0.45 \\
Methionine & 0.62 & 0.57 \\
Lysine & 1.28 & 1.2 \\
TSAA & 1.00 & 0.90 \\
\hline
\end{tabular}

${ }^{*}$ Provides each Kg of diet: Vit. A: 12000 IU, Vit. D3: 5000 IU, Vit. E: $130.0 \mathrm{mg}$, Vit. K3: $3.605 \mathrm{mg}$, Vit. B1: $3.0 \mathrm{mg}$, Vit. B2: $8.0 \mathrm{mg}$, Vit. B6: $4.95 \mathrm{mg}$, Vit. B12: $0.17 \mathrm{mg}$, Niacin: $60.0 \mathrm{mg}$, Folic acid: $2.083 \mathrm{mg}$, D-Biotin: $200.0 \mathrm{mg}$, calcium D-Pantothenate: $18.333 \mathrm{mg}$, Copper: $80 \mathrm{mg}$, lodine: $2.0 \mathrm{mg}$,Selenium: $150.0 \mathrm{mg}$, Iron: $80.0 \mathrm{mg}$, Manganese: $100.0 \mathrm{mg}$, Zinc: $80.0 \mathrm{mg}$,Cobalt $500.0 \mathrm{mg}$.

** Calculated according to NRC (1994).

Table 2. Hatchability (\%), body weight at hatch (BWH) and embryonic mortality (\%) of broiler chicks as affected by in ovo injection with doses of nano Se

\begin{tabular}{|l|c|c|c|}
\hline Items & $\begin{array}{c}\text { Hatchability } \\
\text { (\%) }\end{array}$ & $\begin{array}{c}\text { Embryonic } \\
\text { mortality } \\
\text { (\%) }\end{array}$ & $\begin{array}{c}\text { Chick } \\
\text { weight } \\
\text { at hatch } \\
\text { (g) }\end{array}$ \\
\hline R1 & $96.8^{\mathrm{a}}$ & $3.2^{\mathrm{c}}$ & 45.34 \\
R2 & $93.9^{\mathrm{b}}$ & $6.1^{\mathrm{b}}$ & 45.67 \\
R3 & $86.2^{\mathrm{c}}$ & $13.8^{\mathrm{a}}$ & 45.45 \\
SEM & 1.61 & 1.62 & 0.20 \\
P value & 0.00 & 0.00 & 0.790 \\
Sig. & $* *$ & $* *$ & N.S \\
\hline
\end{tabular}

Mean in the same row within each classification bearing different letters are significantly different, SEM=Standard error of means, $\mathrm{NS}=$ non-significant, ${ }^{* *}(\mathrm{P} \leq 0.01)$.

$\mathrm{R} 1=$ control group, $\mathrm{R} 2=$ in-ovo injection with $5 \mathrm{ppm}$ nanoselenium, $\mathrm{R} 3=$ in-ovo injection with $10 \mathrm{ppm}$ nano-selenium. 
Table 3. Effect of in ovo injection with nano Se on live body weight $(\mathrm{g})$ and body weight gain ( $\mathrm{g} / \mathrm{bird} / \mathrm{day})$ of broiler chicks at different periods

\begin{tabular}{|c|c|c|c|c|c|c|}
\hline \multirow{2}{*}{ Age } & \multicolumn{3}{|c|}{ Experimental groups } & \multirow{2}{*}{ SEM } & \multirow{2}{*}{$P$ value } & \multirow{2}{*}{ Sig. } \\
\hline & R1 & $\mathbf{R 2}$ & R3 & & & \\
\hline & \multicolumn{4}{|c|}{ Live body weight (g) } & & \\
\hline Initial W. & 45.5 & 45.7 & 45.5 & 0.27 & 0.955 & N.S \\
\hline $1^{\text {st }} \mathrm{wk}$ & $153.4^{b}$ & $166.5^{\mathrm{a}}$ & $165.2^{\mathrm{a}}$ & 2.12 & 0.017 & * \\
\hline $2^{\text {nd }} w k$ & 414.4 & 429.1 & 429.9 & 6.04 & 0.497 & N.S \\
\hline $3^{\text {rd }}$ wk & 789.5 & 837.0 & 837.5 & 9.82 & 0.068 & N.S \\
\hline $4^{\text {th }}$ wk & 1350.6 & 1368.2 & 1346.6 & 10.81 & 0.692 & N.S \\
\hline \multirow[t]{2}{*}{$5^{\text {th }} w k$} & 1936.3 & 2000.6 & 1993.8 & 16.7 & 0.221 & N.S \\
\hline & \multicolumn{4}{|c|}{ Body weight gain (g/bird/day) } & & \\
\hline $0-1 w k s$ & $15.3^{b}$ & $17.2^{\mathrm{a}}$ & $17.0^{\mathrm{a}}$ & 0.26 & 0.004 & ** \\
\hline 1-2wks & 37.3 & 37.5 & 37.8 & 0.58 & 0.936 & N.S \\
\hline 2-3wks & $53.6^{\mathrm{b}}$ & $58.3^{a}$ & $58.2^{a}$ & 0.62 & 0.001 & ** \\
\hline 3-4wks & $80.1^{a}$ & $75.9^{b}$ & $72.7^{c}$ & 0.59 & 0.000 & ** \\
\hline 4-5wks & $84.0^{b}$ & $90.35^{a}$ & $92.46^{\mathrm{a}}$ & 1.10 & 0.001 & ** \\
\hline $0-5 w k s$ & 54.1 & 55.8 & 55.7 & 0.47 & 0.241 & N.S \\
\hline
\end{tabular}

Mean in the same row within each classification bearing different letters are significantly different, $\mathrm{SEM}=$ Standard error of means, NS= non-significant, ${ }^{*}(\mathrm{P} \leq 0.05),{ }^{* *}(\mathrm{P} \leq 0.01)$

$\mathrm{R} 1=$ control group, $\mathrm{R} 2=$ in-ovo injection with $5 \mathrm{ppm}$ nano-selenium, $\mathrm{R} 3=$ in-ovo injection with $10 \mathrm{ppm}$ nanoselenium.

Table 4. Effect of in ovo injection with nano Se on feed consumption ( $\mathrm{g} / \mathrm{bird} / \mathrm{day})$ and feed conversion ( $\mathrm{g}$ feed/g gain) of broiler chicks at different periods

\begin{tabular}{|c|c|c|c|c|c|c|}
\hline \multirow{2}{*}{ Age } & \multicolumn{3}{|c|}{ Experimental groups } & \multirow{2}{*}{ SEM } & \multirow{2}{*}{$P$ value } & \multirow{2}{*}{ Sig. } \\
\hline & R1 & $\mathbf{R 2}$ & R3 & & & \\
\hline & \multicolumn{4}{|c|}{ Feed consumption (g/bird/day) } & & \\
\hline $1^{\text {st }}$ wk & $18.6^{\mathrm{b}}$ & $20.2^{a}$ & $21.7^{\mathrm{a}}$ & 0.51 & 0.011 & * \\
\hline $2^{\text {nd }} w k$ & $50.1^{\mathrm{b}}$ & $52.7^{\mathrm{a}}$ & $53^{a}$ & 0.52 & 0.011 & * \\
\hline $3^{\text {rd }}$ wk & $79.9^{b}$ & $87.5^{\mathrm{a}}$ & $81.7^{\mathrm{b}}$ & 1.3 & 0.010 & ** \\
\hline $4^{\text {th }} \mathbf{w k}$ & 124.7 & 121 & 114 & 1.8 & 0.022 & * \\
\hline $5^{\text {th }} w k$ & $136.2^{a}$ & $128.3^{b}$ & $138^{a}$ & 1.7 & 0.010 & ** \\
\hline \multirow[t]{2}{*}{ Overall } & 81.9 & 82.0 & 81.7 & 7.38 & 0.906 & N.S \\
\hline & \multicolumn{4}{|c|}{ Feed conversion (g feed/g gain) } & & \\
\hline $0-1 w k s$ & 1.22 & 1.17 & 1.27 & 0.02 & 0.103 & N.S \\
\hline 1-2wks & 1.35 & 1.41 & 1.4 & 0.03 & 0.598 & N.S \\
\hline 2-3wks & $1.5^{\mathrm{a}}$ & $1.5^{\mathrm{a}}$ & $1.4^{\mathrm{b}}$ & 0.02 & 0.002 & ** \\
\hline 3-4wks & 1.56 & 1.59 & 1.57 & 0.03 & 0.891 & N.S \\
\hline 4-5wks & $1.62^{a}$ & $1.42^{\mathrm{b}}$ & $1.49^{a b}$ & 0.04 & 0.022 & * \\
\hline $0-5 w k s$ & 1.52 & 1.47 & 1.47 & 0.02 & 0.107 & N.S \\
\hline
\end{tabular}

Mean in the same row within each classification bearing different letters are significantly different, $\mathrm{SEM}=$ Standard error of means, NS= non-significant, ${ }^{*}(\mathrm{P} \leq 0.05),{ }^{* *}(\mathrm{P} \leq 0.01)$.

$\mathrm{R} 1=$ control group, $\mathrm{R} 2=$ in-ovo injection with $5 \mathrm{ppm}$ nano-selenium, $\mathrm{R} 3=$ in-ovo injection with $10 \mathrm{ppm}$ nanoselenium. 
In-Ovo Inculation of Selenium Nanoparticles Improves Productive Performance, Blood Biochemical Profile, Antioxidant Status and Immune Response of Hatched Chicks

Table 5. Effect of in ovo injection with nano Se on carcass characteristics of broiler chicks at different periods

\begin{tabular}{|l|c|c|c|c|c|c|}
\hline \multirow{2}{*}{ Items } & \multicolumn{3}{|c|}{ Experimental groups } & \multirow{2}{*}{ SEM } & $\begin{array}{c}\text { P val- } \\
\text { ue }\end{array}$ & \multirow{2}{*}{ Sig. } \\
\cline { 2 - 6 } & $\mathbf{R 1}$ & $\mathbf{R 2}$ & $\mathbf{R 3}$ & & $*$ \\
Body weight (g) & $1955^{\mathrm{b}}$ & $2020^{\mathrm{a}}$ & $1935.3^{\mathrm{b}}$ & 15.9 & 0.044 & $*$ \\
Carcass weight (\%) & 72.1 & 69.4 & 71.8 & 0.72 & 0.286 & N.S \\
Heart weight (\%) & 0.49 & 0.44 & 0.46 & 0.01 & 0.368 & N.S \\
Gizzard weight (\%) & 1.1 & 1.2 & 1.3 & 0.03 & 0.103 & N.S \\
Liver weight (\%) & 2.7 & 2.2 & 2.1 & 0.12 & 0.143 & N.S \\
Total edible weight (\%) & 4.2 & 3.9 & 3.8 & 0.11 & 0.205 & N.S \\
Thigh weight (\%) & 28.9 & 28.0 & 29.9 & 0.41 & 0.183 & N.S \\
Breast weight (\%) & 41.8 & 41.3 & 41.9 & 0.36 & 0.802 & N.S \\
Spleen weight (\%) & 0.11 & 0.10 & 0.10 & 0.01 & 0.358 & N.S \\
Thymus weight (\%) & 0.48 & 0.40 & 0.46 & 0.02 & 0.365 & N.S \\
Bursa weight (\%) & 0.18 & 0.18 & 0.19 & 0.01 & 0.923 & N.S \\
Carcass yield (\%) & 76.3 & 73.3 & 75.6 & 0.71 & 0.193 & N.S \\
\hline
\end{tabular}

Mean in the same row within each classification bearing different letters are significantly different, $\mathrm{SEM}=$ Standard error of means, NS= non-significant, ${ }^{*}(\mathrm{P} \leq 0.05)$.

$\mathrm{R} 1=$ control group, $\mathrm{R} 2=$ in-ovo injection with $5 \mathrm{ppm}$ nano-selenium, $\mathrm{R} 3=$ in-ovo injection with 10 ppm nanoselenium.

Table 6. Effect of in ovo injection with nano Se on total protein, albumin, globulin and A/G ratio of broiler chicks in experimental groups

\begin{tabular}{|c|c|c|c|c|}
\hline Groups Items & $\begin{array}{l}\text { T. protien } \\
\text { g\dl }\end{array}$ & Albumin g\dl & Globulin g\dl & $\mathbf{A} \backslash \mathbf{G}$ ratio $\mathbf{g} \backslash \mathbf{d l}$ \\
\hline R1 & 5.6 & 2.9 & 2.7 & 1.09 \\
\hline $\mathbf{R 2}$ & 5.5 & 3.1 & 2.3 & 1.4 \\
\hline R3 & 6.2 & 3.1 & 3.1 & 1.03 \\
\hline SEM & 0.25 & 0.22 & 0.16 & 0.14 \\
\hline P value & 0.49 & 0.94 & 0.14 & 0.5 \\
\hline Sig. & N.S & N.S & N.S & N.S \\
\hline
\end{tabular}

Mean in the same row within each classification bearing different letters are significantly different, $\mathrm{SEM}=$ Standard error of means, NS= non-significant.

$\mathrm{R} 1=$ control group, $\mathrm{R} 2=$ in-ovo injection with $5 \mathrm{ppm}$ nano-selenium, $\mathrm{R} 3=$ in-ovo injection with $10 \mathrm{ppm}$ nanoselenium.

Table 7. Effect of in ovo injection with nano Se on cholesterol, triglycerides, HDL-cholesterol and LDL- cholesterol of broiler chicks in experimental groups

\begin{tabular}{|l|c|c|c|c|}
\hline Groups Items & $\begin{array}{c}\text { Cholesterol } \\
\text { (mg/dl) }\end{array}$ & $\begin{array}{c}\text { Triglycerides } \\
\text { (mg/dl) }\end{array}$ & $\begin{array}{c}\text { HDL-Cholesterol } \\
\text { (mg/dl) }\end{array}$ & $\begin{array}{c}\text { LDL-Cholesterol } \\
\text { (mg/dl) }\end{array}$ \\
\hline R1 & 148.5 & $166.7^{\mathrm{a}}$ & $48^{\mathrm{b}}$ & 52.1 \\
R2 & 121.9 & $128^{\mathrm{b}}$ & $56.6^{\mathrm{a}}$ & 40.5 \\
R3 & 138.1 & $128.2^{\mathrm{b}}$ & $42.2^{\mathrm{c}}$ & 53.4 \\
SEM & 5.3 & $6.8^{\mathrm{b}}$ & 2.4 & 3.7 \\
P value & 0.105 & 0.001 & 0.019 & 0.347 \\
Sig. & N.S & $\star *$ & ${ }^{*}$ & N.S \\
\hline
\end{tabular}

Mean in the same row within each classification bearing different letters are significantly different, $\mathrm{SEM}=$ Standard error of means, NS= non-significant, ${ }^{*}(\mathrm{P} \leq 0.05),{ }^{* *}(\mathrm{P} \leq 0.01)$.

$\mathrm{R} 1=$ control group, $\mathrm{R} 2=$ in-ovo injection with 5 ppm nano-selenium, $\mathrm{R} 3=$ in-ovo injection with 10 ppm nanoselenium. 
Table 8. Effect of in ovo injection with nano Se on transaminase and alkaline phosphatase of broiler chicks in experimental groups

\begin{tabular}{|c|c|c|c|}
\hline Groups & AST (U/L) & ALT (U/L) & ALP (U/L) \\
\hline R1 & 146.8 & 30.6 & 142.6 \\
\hline R2 & 139.3 & 32.7 & 148.1 \\
\hline R3 & 134.2 & 33.8 & 146.2 \\
\hline SEM & 3.9 & 1.3 & 2.9 \\
\hline$P$ value & 0.661 & 0.484 & 0.784 \\
\hline Sig. & N.S & N.S & N.S \\
\hline
\end{tabular}

Mean in the same row within each classification bearing different letters are significantly different, SEM=Standard error of means, NS= non-significant.

$\mathrm{R} 1=$ control group, $\mathrm{R} 2=$ in-ovo injection with $5 \mathrm{ppm}$ nanoselenium, R3= in-ovo injection with 10 ppm nanoselenium.

Table 9. Effect of in ovo injection with nano Se on uric acid and creatinine of broiler chicks in experimental groups

\begin{tabular}{|l|c|c|}
\hline Groups & $\begin{array}{c}\text { Uric Acid } \\
\text { (mg/dl) }\end{array}$ & $\begin{array}{c}\text { Creatinine } \\
\text { (mg/dl) }\end{array}$ \\
\hline R1 & 4.7 & 0.51 \\
R2 & 4.5 & 0.52 \\
R3 & 4.00 & 0.50 \\
SEM & 0.24 & 0.03 \\
P value & 0.52 & 0.978 \\
Sig. & N.S & N.S \\
\hline
\end{tabular}

Mean in the same row within each classification bearing different letters are significantly different, SEM=Standard error of means, NS= non-significant.

$\mathrm{R} 1=$ control group, $\mathrm{R} 2=$ in-ovo injection with 5 ppm nanoselenium, $R 3=$ in-ovo injection with 10 ppm nanoselenium.

Table 10. Effect of in ovo injection with nano Se on glucose and triiodotherionine (T3) of broiler chicks in experimental groups

\begin{tabular}{|l|c|c|}
\hline Groups & $\begin{array}{c}\text { Glucose } \\
\text { (mg/dl) }\end{array}$ & T3 (ng/ml) \\
\hline R1 & 224.7 & $0.64^{\mathrm{c}}$ \\
R2 & 224.1 & $0.92^{\mathrm{a}}$ \\
R3 & 218.7 & $0.73^{\mathrm{b}}$ \\
SEM & 2.21 & 0.04 \\
P value & 0.535 & 0.002 \\
Sig. & N.S & $\star \star$ \\
\hline
\end{tabular}

Mean in the same row within each classification bearing different letters are significantly different, SEM=Standard error of means, NS $=$ non-significant, ${ }^{* *}(P \leq 0.01)$.

$R 1=$ control group, $R 2=$ in-ovo injection with 5 ppm nanoselenium, R3= in-ovo injection with $10 \mathrm{ppm}$ nanoselenium.
Table 11. Effect of in ovo injection with nano Se on antioxidant status of broiler chicks in experimental groups

\begin{tabular}{|l|c|c|c|}
\hline Groups & $\begin{array}{c}\text { MDA } \\
\text { (nmol/ml) }\end{array}$ & $\begin{array}{c}\text { GSH } \\
(\mathbf{n g} / \mathbf{m l})\end{array}$ & $\begin{array}{c}\text { GSR } \\
\text { (mu/ml) }\end{array}$ \\
\hline R1 & $0.3^{\mathrm{a}}$ & $0.14^{\mathrm{b}}$ & $0.12^{\mathrm{b}}$ \\
R2 & $0.13^{\mathrm{b}}$ & $0.17^{\mathrm{a}}$ & $0.17^{\mathrm{a}}$ \\
R3 & $0.2^{\mathrm{b}}$ & $0.17^{\mathrm{a}}$ & $0.17^{\mathrm{a}}$ \\
SEM & 0.02 & 0.01 & 0.01 \\
P value & 0.00 & 0.041 & 0.013 \\
Sig. & $* *$ & $*^{*}$ & ${ }^{*}$ \\
\hline
\end{tabular}

Mean in the same row within each classification bearing different letters are significantly different, SEM=Standard error of means, ${ }^{*}(P \leq 0.05),{ }^{* *}(P \leq 0.01)$.

$\mathrm{R} 1=$ control group, $\mathrm{R} 2=$ in-ovo injection with $5 \mathrm{ppm}$ nanoselenium, R3= in-ovo injection with 10 ppm nanoselenium.

Table 12. Effect of in ovo injection with nano Se on immunoglobulins ( $\lg G, \lg M$ and $\lg A$ ) of broiler chicks in experimental groups

\begin{tabular}{|c|c|c|c|}
\hline Groups & $\begin{array}{c}\text { IGA } \\
\mathrm{mg} / \mathrm{dl}\end{array}$ & $\begin{array}{l}\text { IGM } \\
\mathrm{mg} / \mathrm{dl}\end{array}$ & $\begin{array}{l}\text { IGG } \\
\mathrm{mg} / \mathrm{dl}\end{array}$ \\
\hline R1 & $106^{c}$ & $75.7^{c}$ & $799.7^{b}$ \\
\hline R2 & $114.7^{b}$ & $125.0^{a}$ & $804.3^{b}$ \\
\hline R3 & $134.7^{a}$ & $82.0^{b}$ & $963^{a}$ \\
\hline SEM & 4.7 & 8.4 & 30.7 \\
\hline$P$ value & 0.007 & 0.004 & 0.013 \\
\hline Sig. & ** & ** & * \\
\hline
\end{tabular}

Mean in the same row within each classification bearing different letters are significantly different, $S E M=S t a n d a r d$ error of means, ${ }^{*}(\mathrm{P} \leq 0.05),{ }^{* *}(\mathrm{P} \leq 0.01)$.

$\mathrm{R} 1=$ control group, $\mathrm{R} 2=$ in-ovo injection with $5 \mathrm{ppm}$ nanoselenium, R3= in-ovo injection with 10 ppm nanoselenium.

\section{REFERENCE}

Bhanja S.K., Mandal A.B. and Johri T.S. 2004. Standardization of injection site, needle length, embryonic age and concentration of amino acids for in ovo injection in broiler breeder eggs. Indian J. of Poultry Sci., 39(2), 105-111.

Britton K., Quinn V., Brown B. and Ekins R. 1975. A strategy for thyroid function tests. $\mathbf{B r}$ Med J, 3(5979), 350-352.

Brown J.G., Bates P.C. , Holliday M.A. and Millward D.J. 1981. Thyroid hormones and muscle protein turnover. The effect of thyroid-hormone deficiency and replacement in thryoidectomized and hypophysectomized rats. Biochemical J., 194(3), 771-782. 
In-Ovo Inculation of Selenium Nanoparticles Improves Productive Performance, Blood

Biochemical Profile, Antioxidant Status and Immune Response of Hatched Chicks

Cai S., Wu C., Gong L., Song T., Wu H. and Zhang L. 2012. Effects of nano-selenium on performance, meat quality, immune function, oxidation resistance, and tissue selenium content in broilers. Poultry Sci., 91(10), 25322539.

Duncan D. 1955. Multiple range and multiple Ftests. Biometrics 11, l-42.

Ebeid A., Zeweil H. and Basyony H. 2013. Fortification of rabbit diets with vitamin $\mathrm{E}$ or selenium affects growth performance, lipid peroxidation, oxidative status and immune response in growing rabbits. Livestock Sci., 155, 323-331.

Edens F., Parkhurst C., Havenstein G. and Sefton A. 2001. Housing and selenium influences on feathering in broilers. J. of Applied Poultry Research, 10(2), 128-134.

El-Deep M.H. , Ijiri D., Ebeid T.A. and Ohtsuka A. 2016. Effects of dietary nano-selenium supplementation on growth performance, antioxidative status, and immunity in broiler chickens under thermoneutral and high ambient temperature conditions. The J. of Poultry Sci., 53(4), 274-283.

Grashorn, M. 2007. Functionality of poultry meat. J. of Applied Poultry Research, 16(1), 99106.

Henry R.J. 1974. Clinical Chemistry Principles and Technics (New York USA: Harper and Row) $407 \mathrm{p}$.

Ishihard A., Kurahasi K. and Uihard H. 1972. Enzymatic determination of 426 ammonia in blood and plasma. Clin. Chem. Acta, 41, 255261.

Jianhua H., Ohtsuka A. and Hayashi K. 2000. Selenium influences growth via thyroid hormone status in broiler chickens. British $\mathbf{J}$. of Nutrition, 84(5), 727-732.

Khazraie S. and Ghazanfarpoor R. 2015. Effect of Nano-Selenium Particles and Sodium Selenite on Performance, Glutathione Peroxidase and Superoxide Dismutase of Quail under Heat Stress. Int. J. Rev. Life. Sci., 5(1), 875-882.

Latshaw J., Morishita T., Sarver C. and Thilsted J. 2004. Selenium toxicity in breeding ringnecked pheasants (Phasianus colchicus). Avian Diseases, 48(4), 935-939.

Levkut M., Revajová V., Levkutova M., Ševčíková Z., Herich R., Borutova R. and Leng L. 2009. Leukocytic responses of broilers following dietary contamination with deoxynivalenol and/or treatment by dietary selenium supplementation. British Poultry Sci., 50(2), 181187.
Macalintal L.M. 2012. 'In ovo selenium (se) injection of incubating chicken eggs: effects on embryo viability, tissue se concentration, lipid peroxidation, immune response and post hatch development', Ph.D. Thesis University of Kentucky, USA.

Mountzouris K.,Tsitrsikos P., Palamidi I., Arvaniti A., Mohnl M., Schatzmayr G. and Fegeros K. 2010. Effects of probiotic inclusion levels in broiler nutrition on growth performance, nutrient digestibility, plasma immunoglobulins and cecal microflora composition. Poultry Sci., 89(1), 5867.

NRC 1994. Nutrient Requirements of Poultry $\left(9^{\text {th }}\right.$ Rev. ed.; Washington, DC: Natl. Acad. Press), Washington, DC. pp. 33-34.

Özbal S., Erbil G., Koçdor H., Tuğyan K., Pekçetin Ç. and Özoğul C. 2008. The effects of selenium against cerebral ischemiareperfusion injury in rats. Neuroscience letters, 438(3), 265-269.

Perić L., Milošević N., Žikić D., Kanački Z., Džinić N., Nollet L. and Spring P. 2009. Effect of selenium sources on performance and meat characteristics of broiler chickens. J. of Applied Poultry Research, 18(3), 403-409.

Pilarczyk B., Jankowiak D.,Tomza-Marciniak A., Pilarczyk R., Sablik P., Drozd R., Tylkowska A. and Skólmowska M. 2012. Selenium concentration and glutathione peroxidase (GSHPx) activity in serum of cows at different stages of lactation. Biological Trace Element Research, 147(1-3), 91-96.

Richmond W. 1973. Preparation and properties of a cholesterol oxidase from Nocardia $\mathrm{sp}$. and its application to the enzymatic assay of total cholesterol in serum. Clinical Chemistry, 19(12), 1350-1356.

Shimizu N., Hosogi N., Hyon G.S. , Jiang S., Inoue K. and Park P. 2006. Reactive oxygen species (ROS) generation and ROS-induced lipid peroxidation are associated with plasma membrane modifications in host cells in response to AK-toxin I from Alternaria alternata Japanese pear pathotype. J. of General Plant Pathology, 72(1), 6-15.

Snedcor G.W. and Cochran W.G. 1982. Statistical Methods $6^{\text {th }}$ Edition ed.; U.S.A.: lowa State Univ., Press, Ames, USA.

Surai P. 2002. Selenium in poultry nutrition 2. Reproduction, egg and meat quality and practical applications. World's Poultry Sci. J., 58(4), 431-450. 
Surai P. and Dvorska J. 2002. Effect of selenium and vitamin $E$ content of the diet on lipid peroxidation in breast muscle tissue of broiler breeder hens during storage. Proc. Ausi. Poult. Sci. Sym., 14, 187-192.

Wang Y.B. and Xu B.H. 2008. Effect of different selenium source (sodium selenite and selenium yeast) on broiler chickens. Animal Feed Sci. and Technology, 144(3-4), 306-314.

Yoon I., Werner T. and Butler J. 2007. Effect of source and concentration of selenium on growth performance and selenium retention in broiler chickens. Poultry Sci., 86(4), 727-730.

Zhang J.S., Gao X.Y., Zhang L.D. and Bao Y.P. 2001. Biological effects of a nano red elemental selenium. Biofactors, 15(1), 27-38.

Zhou X. and Wang Y. 2011. Influence of dietary nano elemental selenium on growth performance, tissue selenium distribution, meat quality, and glutathione peroxidase activity in Guangxi Yellow chicken. Poultry Sci., 90(3), 680-686. 


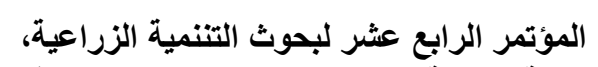

التأثيرات التحسينية لحقن البيض بجزيئات السلينيوم متناهية الصغر على الآداء الإنتاجي والصفات البيوكيميائية للام ومضادات الأكسدة والإستجابة المناعية في الكتاكيت الفاقسة الأسية

نور الدين جودة محمد1" - إبراهيم الورداني السيد² - يسري محمد الحمصاني2 - ماجدة محمد وكوك 1 [81]

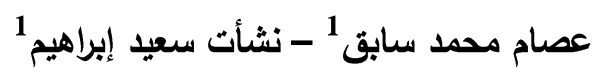

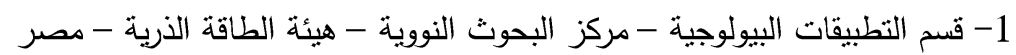
2- قسم إنتاج الدواجن- كلية الزراعة - جامعة عين شمس - ص.ب 68 - 6 - حائق شبرا 11241 - القاهرة - مصر

*Corresponding author: noureldeen.goda@gmail.com

Received 30 December, 2018

Accepted 8 January, 2019

وهرمون T3 وإنزيم الجلوتاثيون ريدكيتيز ومركب الإنيان

، الجلوتاثيون هيدروجينيز والأجسام المناعية IGA

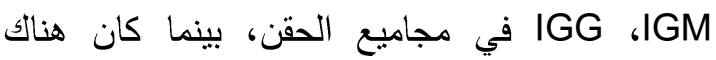
إنخفاض معنوي في معامل تحويل الغذاء والدهون

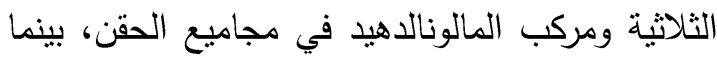
لم يتأثر وزن الكتكوت الفاقس وكمية الغذاء المأكول

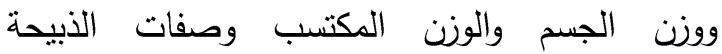
وبروتينات الدم والكوليسترول وجزيئات الدهون منخفضة الكثافة وإنزيمات الكبد وحمض اليوريك والكرون والكرياتين

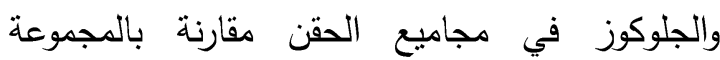
الضابطه، يخلص من هذه الدراسة أن حقن مستويات

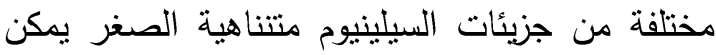

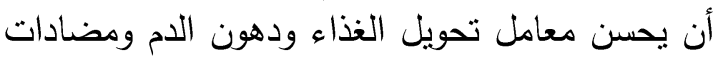
الأكسدة والمناعة في الكتاكيت الفاقسة.

الكلمات الدالة: السيلنيوم، الكتاكيت، الخصوبة

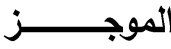

يعتبر السيلنيوم عنصر ضروري في تغذية الحيوان حيث إنه يحسن إنتاج الحيوان والخصوبة والإستجابة فئان

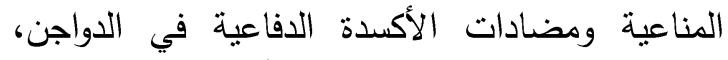

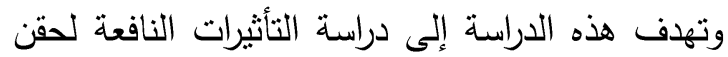
البيض بجزيئات السيلنيوم متتاهية الصغر الصنافية دلى الآداء الإنتاجي وسرعة تحفيز مضادات الأكسدة الدفاعية الإنية الإنية

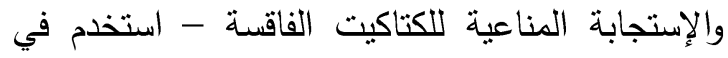
هذه الدراسة عدد 210 بيضة بدارية الإئة تسمين حيث قسمت إلى ثلاثة مجاميع معاملة ثم حقنها بجزيئات السيلنيوم بتركيز (0، 5، 10 جزء في المبلة المليون) أثناء مرحلة التفريخ. تم تقييم صفات الفقس والآداء الإنتاجي الميون وصفات الام البيوكيميائية وبعض مضادية لفادات الأكسدة

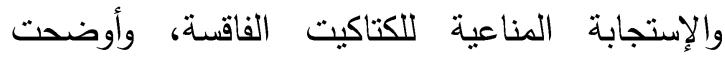
النتائج زيادة معنوية في جزيئات الدهون عالية الكثافة 